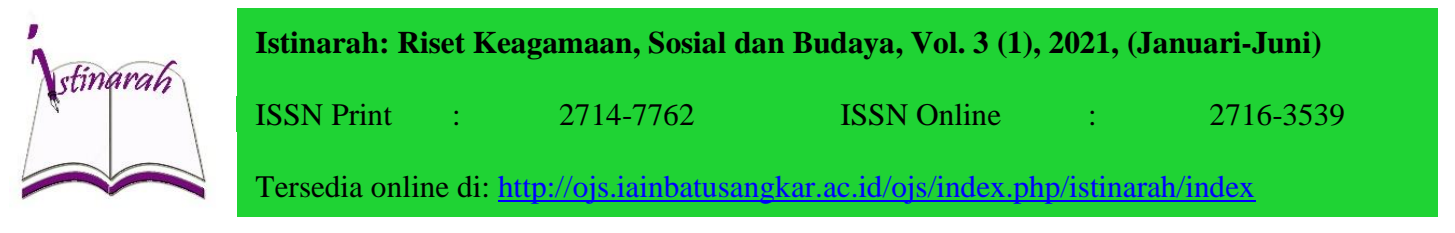

\title{
Pemanfaatan Foto Jurnalistik Oleh Pos Metro Padang pada Pemberitaan Koran
}

\section{Izzatul Mufidah}

Institut Agama Islam Negeri

Batusangkar, Sumatera Barat, Indonesia

E-mail:

mufidahizzatu@gmail.com

\section{Refika Mastanora}

Institut Agama Islam Negeri

Batusangkar, Sumatera Barat,

Indonesia

E-mail:

refikamastanora@iainbatusangkar.ac.id

*) Corresponding Author

\begin{abstract}
Abstrak: Foto jurnalistik tidak bisa dilepaskan dari media massa karena perkembangan media massa, baik cetak, elektronik maupun online, memicu setiap orang untuk membuat dan mendapatkan foto yang bagus dari media pilihannya. Penelitian ini menggunakan metode kualitatif deskriptif yang bertujuan untuk mengungkapkan kejadian atau fakta, keadaan, fenomena yang terjadi pada saat penelitian berlangsung. Informan penelitian adalah wartawan Pos Metro Padang. Teknik pengumpulan data yang peneliti gunakan adalah observasi, wawancara dan dokumentasi. sedangkan keabsahan data menggunakan metode triangulasi sumber. Hasil penelitian menunjukkan bahwa foto jurnalistik di Pos Metro Padang bersifat aktual, memberikan informasi, mangandung unsur kebaruan, memiliki keaslian yang tinggi serta memberikan respon terhadap masyarakat. Jurnalis Pos Metro Padang mengutamakan kepentinagn umun dari pada kepentingan instansi, karena berita yang diperoleh bersumber dari masyarakat dan dipublikasikan untuk masyarakat itu sendiri.
\end{abstract}

\begin{abstract}
Photojournalism cannot be separated from the mass media because the development of mass media, whether printed, electronic or online, has triggered everyone to make and get good photos from the media of their choice. This study uses descriptive qualitative methods that aim to reveal events or facts, circumstances, phenomena that occur during the research. The research informants were journalists of Pos Metro Padang. Data collection techniques that researchers use are observation, interviews and documentation. while the validity of the data used the source triangulation method. The results showed that photojournalism at Pos Metro Padang was actual, provided information, contained an element of novelty, had high authenticity and provided a response to the community. Journalists of Pos Metro Padang prioritize general interests rather than agency interests, because the news they get comes from the public and is published for the community itself.
\end{abstract}

Kata kunci: Pemanfaatan, Foto Jurnalistik, Pemberitaan

PENDAHULUAN

Setiap foto harus mampu memukau

indra dan perhatian orang seketika itu.
Bagaimana pun tampilannya, ketika dipamerkan di ruang publik, sebuah foto mempunyai pengaruh yang sangat 
kuat, dapat mengantarkan perasaan dan menggugah pikiran orang yang melihat dan membacanya."Tanpa gambar, aksara tak bermakna", begitulah kata pepatah lama. Fotografi adalah seni melihat yang dapat memberikan banyak kisah atas berbagai momen yang terjadi.

Perkembangan teknologi kamera menyebabkan siapa saja bisa membuat foto yang menarik, entah foto dirinya, keluarga, lingkungan, atau apa pun yang ada di sekitarnya. Fotografi mengajarkan kepada kita cara yang unik sekaligus memberikan penyadaran baru akan keindahan di sekitar kita. Apalagi dengan semakin beragamnya media jejaring sosial yang memberikan kesempatan kepada setiap orang untuk "memamerkan" fotonya.

Membahas foto jurnalistik tidak bisa dilepaskan dari media massa karena perkembangan media massa, baik cetak, elektronik maupun online, memicu setiap orang untuk membuat dan mendapatkan foto yang bagus dari media pilihannya. Meskipun lebih lambat dibandingkan dengan jurnalistik tulis, perkembangan jurnalistik foto sangatlah cepat. Bahkan, saat ini hampir semua media massa menyajikan karya foto jurnalistik dalam setiap terbitannya. Kondisi ini tidak bisa lepas dari era fotografi digital. Perubahan ini tidaklah mengabaikan berbagai teori yang ada pada fotografi manual karena perubahan ini terjadi hanya pada prosesnya saja. Bila dulu untuk mengirimkan foto ke redaksi memerlukan jasa pos atau kurir, saatini perkembangan teknologi memungkinkan setiap jurnalis foto mengirimkan hasil fotonya ke redaksi melalui telepon genggam yang dibawanya.

Foto dalam kerja jurnalistik mempunyai peranan yang sangat penting ibarat masakan, foto dalam surat kabar atau majalah dapat diumpamakan sebagai bumbu penyedap, bahkan foto berperan untuk mempercantik wajah media cetak dan membuat pembaca tertarik untuk membaca. Apapun dan bagaimanapun bentuk foto itu, akan merupakan variasi yang sama sekali lain dengan tulisan yang hanya berisi huruf-huruf yang teratur rapi, namun demikian, sebagai penyedap tidak 
semua foto dapat dimasukan atau ditampilkan pada surat kabar atau majalah. Ada kaidah-kaidah yang harus dipenuhi dalam menampilkan foto pada surat kabar atau majalah. (Fardiana, 2014: 9-10)

Foto jurnalistik, menurut Thomas Elliot Berry dalam Widyatmoko (2016: 211-212), memiliki sejumlah fungsi. Pertama, untuk mengomunikasikan berita (to communicate the news), foto memiliki nilai yang sangat penting dalam penyampaian berita, bukan sekedar pelengkap atau aksesoris dari pesan yang ingin disampaikan komunikator. Ia menyempurnakan sajian suatu berita. Tanpa kehadiran foto, berita tersebut akan terasa hambar, tidak berbunyi. Kedua, foto jurnalistik menimbulkan minat (to generate interest). Ketiga, foto jurnalistik berfungsi untuk menonjolkan dimensi lain dari sebuah objek pemotretan yang dipublikasikan (to give another dimension to a newsworthy figure). Keempat, foto jurnalistik berfungsi untuk menambah nilai berita (sisi kualitas pemberitaan) tanpa mengurangi arti berita. Kelima, foto jurnalistik dimanfaatkan untuk keperluan tata rias/perwajahan surat kabar dan majalah secara garis besar yang bisa memberikan dampak pada seluruh perwajahan.

Penggunaan foto pada media cetak yang ada di Sumatera Barat dianggap menjadi hal penting dalam unsur pemberitaan yang ada. Media Pos Metro Padang merupakan salah satu media cetak yang masih menjaga keeksisannya dalam menerbitakan sebuah pemberitaan di media cetak. Dalam media Pos Metro Padang tersebut penggunaan foto untuk memperkuat dan mempertajam pemberitaan dianggap menjadi aspek yang dapat menjaga keorisinalan berita.

Foto jurnalistik yang digunakan untuk pemberitaan oleh Pos Metro Padang tidak terlepas dari berita umum, bencana alam, kriminal, olahraga dan sesuatu yang menyentuh masyarakat. Untuk menentukan foto itu layak atau tidaknya dilihat dari domainnya, apakah angel dari berita itu sesuai dengan angel foto yang diambil. Pos Metro Padang menerbitkan enam puluh berita setiap 
harinya. Dari banyaknya berita ada beberapa yang tidak menggunakan foto.

\section{METODE PENELITIAN}

Jenis penelitian yang penulis gunakan yaitu penelitian deskriptif menggunakan pendekatan kualitatif. Penelitian deskriptif adalah penelitian yang berusaha mendeskripsikan suatu gelaja, peristiwa, kejadian yang terjadi pada saat sekarang. Penelitian deskriptif memusatkan perhatian pada masalah aktual sebagaimana adanya pada saat penelitian berlangsung. (Noor, 2013: 34)

Penelitian ini dilaksanakan di Pos Metro Padang, dengan mencari informasi kongrit tentang Pemanfaatan Foto Jurnalistik Oleh Pos Metro Padang Pada Pemberitaan Koran. Setelah memperoleh informasi, penulis akan mendeskripsikan untuk memberikan gambaran. Sedangkan waktu pelaksanaan penelitian pada bulan Agustus 2020- September 2020. Dalam penelitian kualitatif, yang menjadi instrumen kunci penelitian adalah peneliti itu sendiri. Menurut Sugiyono (2013:22) instrumen utamanya adalah peneliti itu sendiri, namun setelah fokusnya jelas, maka akan dikembangkan instrumen penelitian sederhana, yang diharapkan dapat melengkapi data membandingkan dengan data yang ditemukan melalui observasi, wawancara dan dokumentasi.

Dalam melakukan penelitian tersebut, peneliti perlu dibantu dengan instrumen pendukung, seperti: filednotes, hand came, recorder, dan lain-lain (Buku Pedoman Penulisan skripsi IAIN Batusangkar, 2017:29). Adapun instrumen pendukung yang peneliti gunakan dalam penelitian ini adalah menggunakan handphone untuk merekam hasil wawancara, dan membuat dokumentasi saat pelaksanaan wawancara. Berdasarkan dengan itu, sumber data dalam penelitian ini terbagi menjadi dua yaitu: data primer dan data sekunder.

Dalam penelitian ini penulis menggunakan tringulasi sumber sebagai validitas data, yang mana triangulasi ini bertujuan untuk menguji dan menjamin keabsahan data yang diperoleh dari beberapa sumber data. 


\section{HASIL DAN PEMBAHASAN}

Berdasarkan hasil wawancara dan obsservasi peneliti terkait proses pemuatan foto jurnalistik pada koran Pos Metro Padang memiliki nilai autentifikasi yang tinggi, sehingga memiliki ke khasaan suatu media cetak. Hampir semua isi berita berasal dari tindak kasus pidana dan kasus kriminal yang membuat koran ini di kenal sebagai "koran berdarah"

Proses pemuatan foto jurnalistik dalam pemberitaan di koran Pos Metro Padang mengacu pada proses pemuatan sebuah foto dalam surat kabar diawali dari peliputan jurnalis di lapangan. Setelah itu, ia memilih hasil foto terbaiknya dan menyerahkan foto tersebut kepada redaktur. Redaktur mengedit foto yang diberikan sesuai dengan kaidah aturan foto jurnalistik, kemudian menyerahkan kepada redaktur lainnya untuk diberi caption. Setelah lengkap, foto diserahkan ke bagian layout untuk diatur tata letaknya di halaman surat kabar. File yang sudah lengkap diserahkan kepada koordinator peliputan lapangan dan koordinator foto lapangan. Proses akhir berada pada redaktur pelaksana yang memeriksa keseluruhan isi berita. Jika semua telah siap, keputusan akhir dimuat atau tidaknya sebuah foto jurnalistik ditentukan oleh pimpinan redaksi. Foto yang dimuat dalam surat kabar ini merupakan foto yang telah melalui seleksi dari beberapa pihak sebelumnya. Sehingga terdapat beberapa foto yang di anggap sesuai dan layak untuk diberitakan.

Foto yang dimuat dalam koran Pos Metro Padang tidak lepas dari kode etik jurnalistik foto dalam pemberitaan. Berdasarkan hasil wawancara yang peneliti dapatkan koran Pos Metro Padang menjunjung tinggi hak dan privasi masyarakat dalam proses pemberitaan. Karena berita yang diperoleh oleh jurnalis bersumber dari masyarakat dan dipublikasikan kepada masyarakat itu sendiri. Ketika foto diedit untuk disiarkan di media massa cetak (dipublikasikan menjadi foto jurnalistik), ada batasan yang diperhatikan. Hal ini untuk menjaga agar nilai-nilai jurnalistik tetap terjaga dalam foto yang diedit tersebut. Sebagaimana aturan yang ada dalam 
Kode Etik Jurnalistik (KEJ-KEWI), Pasal 2, yaitu Wartawan Indonesia menempuh cara-cara yang profesioanal dalam melaksanakan tugas jurnalistik. Penafsiran ini sebagaimana terdapat dalam poin "e", yakni rekayasa pengambilan dan pemuatan atau penyiaran gambar, foto, suara dilengkapi dengan keterangan sumber dan ditampilkan secara berimbang.

Foto berita harus merupakan foto perstiwa yang benar-benar terjadi (echt) karena bila terjadi pemalsuan atau penipuan dalam jangka panjang akan terjadi penolakan atas dasar pengalaman yang negatif. Berdasarkan hasil wawancara dan observasi yang peneliti lakukan terhadap peran dari kode etik jurnalistik terhadap foto yang digunakan juga berpengaruh pada etika dari fotografer jurnalistik dalam pengambilan foto tersebut. Menurut informasi dan data yang peneliti dapatkan, tindakan plagiasi merupakan suatu tindakan yang tidak baik dan bertentangan dengan undang-undang yang berlaku. Itu di atur dalam undangundang No 19 Tahun 2002.Dalam proses peliputan foto, jurnalis foto seringkali harus menghadapi masalah antara perasaan dengan kepentingan tugas.

\section{KESIMPULAN}

Berdasarkan hasil penelitian, Proses pemuatan foto jurnalistik dalam pembuatan berita di Pos Metro Padang bersifat aktual, memberikan informasi kepada masyarakat, mengandung unsur kebaruan, memiliki keaslian yang tinggi serta memberikan respon terhadap masyarakat. Proses pemuatannya berlangsung di mulai dari peliputan oleh jurnalis, penyeleksian oleh koordinator liputan, pengeditan yang di lakukan oleh layouter sampai terpilih foto yang layak untuk dipublikasikan kepada masyarakat.

Kode etik jurnalistik dalam penggunaan foto di Pos Metro Padang menjunjung tinggi hak masyarakat dalam memperoleh sebuah karya foto jurnalistik. Jurnalis harus mengutamakan kepentingan umum dari pada kepentingan instansi, karena berita yang diperoleh bersumber dari masyarkat dan dipublikasikan untuk masyarakat itu sendiri. Jika ada yang 
melakukan tindakan plagiasi terhadap foto jurnalistiik saat pemberitaan sebuah berita akan dikenakan kode etik jurnalistik. Yang diatur dalam undangundang No 19 Tahun 2002.

\section{REFERENSI}

Buku

Alwi M. Audy. 2016. Foto Jurnalistik. Catakan keenam. PT Bumi Aksara. Jakarta

Gani R. dan K. R. Rizki. 2013. Jurnalistik Foto. Cetakan Pertama. PT Remaja Rosdakarya. Bandung.

Hidayatullah. A. 2016. Jurnalisme Cetak Konsep dan Praktik. Litera Yogyakarta. Yogyakarta

IAIN Batusangkar. 2107. Buku Pedoman Penulisan Skripsi IAIN Batusangkar. Batusangkar: IAIN Batusangkar

Moleong, Lexy J. 2006. Metodologi Penelitian Kualitatif. PT Remaja Rosdakarya. Bandung

Noor, J. 2013. Metodologi Penelitian: Skripsi, Tesis, Disertasi dan Karya Ilmiah. Jakarta: Prenada Media Group.

Putera, N. 2012. Penelitian Kualitatif: Proses \& Aplikasi. Jakarta Barat: Permata Puri Media

Rahmat Ikbal dan Abdurrahman. 2017. Fotografi Jurnalistik. Modul Pembelajaran FIKOM Esa Unggul. Agustus 2017. Jakarta
Romli, A. Syamsul M. 2008. Kamus Jurnalistik. Cetakan pertama. Simbiosa Rekatama Media. Bandung

Sugiyono. 2013. Metode Penelitian Kuantitatif, Kualitatif, dan $R \& D$. Alfabeta.Bandung

Yunus Syafrudin. 2015. Jurnalistik Terapan. Cetakan Ketiga. Ghalia Indonesia. Bogor

\section{Jurnal}

Azhar F. 2018. Kajian Foto Jurnalistik Demonstrasi 1998 Karya Julian Sihombing. Jurnal DESAIN. 6 (01): 57

Darmawan F. 2005. Jurnalistik Foto Diera Digital: Antara Teknologi dan Etika. Jurnal Mediator. 1 (1): $28-29$

Fardiana.2014. Analisis Penyajian Foto Berita Pada Surat Kabar Harian Umum Rakyat Bengkulu. Jurnal Profesional FIS UNNIVED. 1 (1): $9-10$

Gamala, N. Tri. 2016. Implementasi Kode Etik Jurnalistik Pada Foto Jurnalistik Dalam Rubrik Hukum Kriminal Di Portal Berita GoRiau.com. Jurnal Ilmu Komunikasi, Konsentrasi Jurnalistik 3 (2): 6-7

Husaebah, S. 2014. Peningkatan Kompetensi Dalam Proses Pembelajaran. Jurnal Ilmu Perpustakaan \& Kearsipan Khizanah Al-Hikmah. 2 (2): 2-3 
Nuswantara, J. P. 2014. Pesan Sosial Dalam Foto Jurnalistik. Jurnal Ilmu Komunikasi Universitas Semarang. 6 (1): 15-16

Payoka, V. 2016. Analisi Isi Foto Jurnalistik Pada Kolom Citizen. Jurnal Ilmu Komunikasi Fakulatas Ilmu Sosial dan Ilmu Politik 3 (20): 3-4 